Resumen por el autor, Warren Lewis.

La cualidad adhesiva de las células.

Es evidente que las células que emigran sobre la superficie inferior del cubreobjetos en los cultivos de tejidos son adhesivas; de otro modo, cuando se emplea un medio de cultivo líquido, caerían al fondo de la gota, puesto que son más pesadas que el medio. Las células son adhesivas a consecuencia del mismo material de que están formadas, del mismo modo que la cola es pegajosa. Sin esta cualidad adhesiva al vidrio y algunos otros sólidos, no podrían emigrar. No existe razón alguna para creer que desarrollan esta cualidad cuando abandonan el trozo cultivado y vienen a ponerse en contacto con el vidrio. Esta cualidad adhesiva varía un tanto, puesto que las células pueden redondearse y desprenderse del cubreobjetos. Este fenómeno es pasivo y no corresponde de modo alguno a la sensibilidad que exhiben ciertos animales para los sólidos, conocida con el nombre de estereotropismo. Las células se adhieren no solo al vidrio y otros sólidos, sino también entre sí en grado variable. Esta cualidad adhesiva juega un papel muy importante en la persistencia del contacto de las células y los diversos tejidos, no solo durante la segmentación y en el embrión antes de formarse las fibras intercelulares, sino también en el adulto. La existencia de continuídad protoplásmica actual, es muy dudosa en la mayor parte de los tejidos, tales como el mesenquima, epitelio y músculo. De tal modo que si las células de nuestro cuerpo perdiesen súbitamente su cualidad adhesiva, nos desintegraríamos repentinamente y los varios tipos celulares formarian una corriente mezclada de ectodermo, músculo, mesenquima, hígado y otros varios tipos celulares.

Translation by Josê F. Nonidez

Cornell Medical College New York 
AUTHOR'S ABSTRACT OF THIS PAPER ISSUED

BY THE BIBl, IOGRAPHIC SERVICE, JUNE 12

\section{THE ADHESIVE QUALITY OF CELLS}

WARREN H. LEWIS

Carnegie Laboratory of Embryology, Johns Hopkins Medical School

From observations on the behavior of cells in tissue cultures, it seems to me that the causative factors in the phenomena exhibited by the cells in their migration out from the explant along solid supports resolve themselves into two separate categories: 1) a natural stickiness or adhesiveness which these cells appear to have for certain solids and for each other; 2) the forces that cause them to migrate. Concerning the first very little has been written, although I think we have all been aware that many cells are sticky. We have long known, for example, of the adhesive quality of white blood-cells for glass. The importance of this adhesive quality in the various body cells, however, has been almost entirely ignored. Yet most of our tissues and organs are made up of cells that are merely stuck together. Were these various types of cells to lose their stickiness for one another and for the supporting extracellular white fibers, reticuli, etc., our bodies would at once disintegrate and flow off onto the ground in a mixed stream of ectodermal, muscle, mesenchyme, endothelial, liver, pancreatic, and many other types of cells.

It will seem to many that I am overlooking a very important consideration, namely, the so-called syncytial relations supposed to exist in many tissues, such as the smooth muscle, heart muscle, and especially the mesenchyme, as also the ectoderm, by virtue of its so-called intercellular bridges. I am convinced, after the study of the behavior of these cells in tissue cultures of chick embryos, that the outgrowths of these tissues do not form syncytia. From this it would appear highly probable that they do not form syncytia either in embryos of four to ten days' incubation (the usual ages from which the tissues were taken for cultures) or in the adult, and that this holds true not only for birds, 
but for mammals as well. Some of the evidence for the nonsyncytial nature of mesenchyme has already been published: and that for heart muscle, smooth muscle, and ectoderm is nearly ready for publication.

It is almost self-evident that the cells that migrate out on the under surface of the cover-glass, in cultures where a fluid medium is employed, are sticky for glass. They are often apparently quite firmly adherent, and such preparations can be washed and manipulated in various ways and with various fluids, or even fixed and killed by different agents, without disturbing their attachment. They can even be poked with a needle or centrifugalized, and yet the cells will not be dislodged. Of course, cells do frequently become detached from the glass through manipulations of various sorts, or they may at times round up and drop to the bottom of the hanging-drop, but even after rounding up many still remain attached. Not only the bodies, but the cell processes as well possess this adhesive quality, and it not infrequently happens that an outgrowth, contracting back towards the explant, snaps apart some of the more extended processes at the periphery, leaving slender, isolated fragments of cytoplasm adhering to the cover-glass. The adhesiveness of such fine processes, some of them so thin as to be almost invisible, can scarcely be explained on any other ground than stickiness. It is highly improbable that the adhesion is maintained by some sort of suction apparatus. I do not quite see how it could be proved that the cells are or are not sticky for glass before they come into contact with it, and there is no particular reason for believing that they develop such a special adhesive quality as they leave the explant and come in contact with the cover-slip.

Cells are not only sticky for the cover-glass, but for each other as well. In the body of the embryo and in the tissue explant such cells as endothelium, mesothelium, and the endodermal lining of the intestine are undoubtedly merely adherent to their neighbors, but they retain their adhesive quality in the outgrowths and, in addition, stick to the cover-glass. I believe the same thing is true for those cells that have hitherto been supposed to form syncytia.

${ }^{1}$ Lewis, W. H. Is mesenchyme a syncytium? Anat. Rec., vol. 23, 1922. 
We may in time be able to measure the force of the adhesions in some way, as by utilizing the centrifugal force necessary to dislodge them, but so far even the high speed of the ordinary centrifuge fails to move those that are flattened out to any extent from their attachment to the cover-glass. The fact that cells do move and shift about, spread out very flat, or round up and drop off indicates that the factors of cohesion and surface tension of the protoplasm are constantly at work in altering the extent and position of the adherent areas, both on the cover-glass and on the other cells. Such changes may very well take place without altering the natural adhesiveness of the surface of the cells, but it is entirely possible that the degree of stickiness also may vary. One wonders whether this sticky quality is dependent upon the composition of the protoplasmic surface membrane that limits all cells or upon some sort of substance that is secreted by the cell as one of the products of its metabolism. The so-called cement, so commonly described as existing between various types of cells, may possibly be an adhesive substance. This is usually recognized by its power to reduce silver nitrate. Now, most living cells in our cultures show a slight browning over their entire surface with silver nitrate, while dead cells do not: it is therefore possible that the silver nitrate is reduced by the living protoplasm and not by any substance on its surface. The heavy lines seen at the contact edges of cells seem to be, in part at least, an optical effect of looking edgewise at a thin granular film.

The important rôle which this adhesive quality plays in the early stages of development, before the formation of extracellular fibrils of any sort, can scarcely be overestimated. Without it multicellular organisms could not exist. When it is repressed, as was done by Herbst $\left({ }^{\prime}(00)^{2}\right.$ in the segmentation stages of certain marine animals, by eliminating calcium salts from the sea-water, the blastomeres fall apart and round up and further development of the embryo becomes impossible. In the blastula and gastrula stages the only other factor that might play a rôle in keeping

2 Herbst, Curt. Ueber das Auseinandergehen von Furchungs- und Gewebezellen in kalkfreiem Medium. Arch. f. Entw. Mech., Bd. 9, 1900, S. 424. 
the cells in position is the presisure from without of an external membrane inclosing the whole organism. I am eliminating entirely the conception of intercellular bridges, which has been postulated by Hensen ${ }^{3}$ and others, and have adopted the opposite extreme, which may seem to many as far from the truth as the idea of universal cell continuity. In the early embryonic stages, before the formation of extracellular fibrils and other supporting and binding substances, whether these be in the form of gels or of fibers, all the tissues are held together by adhesion or a combination of adhesion and interlacing of elongated and branched cells. In later stages and in the adult the extracellular supporting substances play an important rôle in holding cells and tissues together, but the intercellular adhesions are probably still more important.

The most obvious deduction to draw from the known facts is that the cells in tissue cultures are sticky as regards certain solids, and that this is a natural characteristic. They are sticky because of the very material of which they are composed, just as egg albumen, glue, and mucilage are sticky. If, then, we admit that the cell surface is naturally sticky for glass, we can scarcely consider that adhesion of the cells to solids is a form of tropism. 'Tropism' as the term is usually employed, applies to the phenomenon observed in living organisms of moving toward (positive) or away from (negative) a focus of light, heat, a solid body (stereotropism), or other stimulus. The term 'stereotropism' has frecuently been employed to indicate a reaction exhibited by all of the cells in tissue cultures that migrate out from the explants on solid supports. Harrison ('11, '14) and others have observed that cells that migrate out from the explant always utilize some solid support, such as the cover-glass, fibrin threads, spider-web, fibers of various sorts, or even the surface film of the fluid hanging-drop. None of the ordinary tissue-cells are able to swim about in fluid media. The idea

\footnotetext{
"Hensen, $V$. Ueberdie Lntwicklung des Gewebes und der Nerven im Schwanze des Froschlarve. Virchow's Ireh., Bal, 31, 1864.

Harrison, R. C. The reaction of embryonic cells to solid structures. Jour. Exp. Zö̈l., vol. 17, 1914. Sicience, vol. 34, 1911.
} 
underlying the use of the term stereotropism, as applied to the cells in tissue cultures, seems to be that there is some sort of positive reaction on the part of the cells toward the solid. Cells migrate only on solids; therefore it is assumed they are in some way attracted by solids. The following quotation from Harrison ('14, p. 541) indicates the present attitude on the subject:

"While it must therefore be admitted that chemical stimuli may play an important part in influencing the movements of cells in simple cultures, as Burrows has pointed out, the facts show that the cells are also stimulated by solids as such and respond to them by an orienting movement. Response to tactile stimuli is of such general occurrence in animals that there is nothing anomalous in the manifestation of the same kind of sensitiveness in cells."

We say that cells are stereotropic because they have only been observed to migrate on solids, and that they migrate on solids because they are stereotropic. To say that cells are stereotropic does not offer any explanation for the fact that they migrate only on solids. On the other hand, the fact that they can only migrate on solids does not necessarily mean that they are stimulated by solids as such, nor is there any reason to believe in a sensitiveness of cells that corresponds in any way to the response of animals to tactile stimuli. The adhesion of cells to solids is a passive phenomenon. Since cells are heavier than the fluid medium, they could not migrate on the under surface of the cover-slip unless they were adherent.

Concerning the factors which cause the cells to migrate out from the explant along the cover-glass or other solids, on the surface film of a liquid drop, or on other cells (which behave as solids), there is still much uncertainty. The work of Tait ('18) and Leo Loeb $(20)^{\circ}$ indicates that the progressive movements

\footnotetext{
5 Tait, J. The capillary phenomena observed in blood cells, etc. Quart. J. Exp. Physiol., vol. 12, 1918.

${ }^{6}$ Loeb, Leo. The movements of the amoebocytes and the experimental production of amoebocyte (cell-fibrin) tissue. Wash. Univ. Studies, vol. S, Scientific Series no. 1, 1920.
} 
of the cells may depend upon local variations in the metabolism which produce local changes in the fluidity and surface tension of the cells, while the observations of Burrows ${ }^{7}$ suggest that the interchange of substance between explant and medium may offer a basis for a differential localization of metabolism.

${ }^{7}$ Burrows, M. T. The tissue culture as physiological method. Trans. Cong. Amer. Physicians and Surgeons, vol. 9, 1913. 